\title{
Evaluation of techno-functional attributes of starter culture for preparation of Greek- style yogurt
}

\author{
Jyoti Singh and Surajit Mandal
}

Received: 27 June 2018 / Accepted: 19 November 2018 / Published online: 21 February 2019

(C) Indian Dairy Association (India) 2019

\begin{abstract}
Greek yogurt, a fermented semi-solid product, is derived from yogurt by draining away part of its water and watersoluble components. The present study is an attempt to formulate good quality yogurt cultures by using different strains of Streptococcus thermophilus (ST) and Lactobacillus bulgaricus (LB). Co-culturing was done in milk ( $3 \%$ fat, $15 \%$ total solid and based on acidification profile, curd setting time, body, texture and culture ratio, $5 \mathrm{ST}$ and $3 \mathrm{LB}$ cultures were selected. Selected cultures were evaluated for technological properties like growth and acidification profile, flavour and CPS production in skim milk with 15 and $25 \% \mathrm{TS}$ ) at $42^{\circ} \mathrm{C} / 6 \mathrm{~h}$. Acidification and growth profile of selected cultures were comparable at 15 and $25 \%$ of total solids (TS) in skim milk. All five $S$. thermophilus cultures were positive for acetaldehyde production and galactose fermentation. Cultures, NCDC 526 and 435 were found with highest galactose utilization as determined by HPLC. All selected cultures were positive for CPS production. The proteolytic activity of selected cultures (S. thermophilus and L. bulgaricus) were checked in skim milk at $42^{\circ} \mathrm{C} / 6 \mathrm{~h}, \mathrm{NCDC} 526$ found with lowest and I15 with highest proteolytic activity. Therefore, study of these parameters are important for achieving the best technological performance regarding the selection of cultures to formulate culture
\end{abstract}

Jyoti Singh

TFSL, Dairy Microbiology Division, ICAR-National Dairy Research Institute, Karnal-132001, Haryna, India

Surajit Mandal $(\square)$

TFSL, Dairy Microbiology Division, ICAR-National Dairy Research Institute, Karnal-132001, Haryana, India

Email: mandalndri@rediffmail.com combinations for preparation of good quality yogurt and Greekstyle yogurt at commercial scale.

Keywords: Fermentation, Greek yogurt, Greek-style yogurt, Milk solids, Ultra filtration

\section{Introduction}

Yogurt is a fermented product produced by culturing one or more of the optional dairy ingredients cream, milk, partially skimmed milk or skimmed milk, used alone or in combination with a characterizing bacterial culture that contains the lactic acid producing bacteria, L. bulgaricus and S. thermophilus (Jorgensen et al., 2018). Yogurt is an excellent source of protein calcium, phosphorus, potassium and contains significant quantities of general vitamins. Greek yogurt is a fermented semi-solid product derived from yogurt by draining away part of its water and watersoluble components until a level of $23-25 \mathrm{~g}$ total solids $/ 100 \mathrm{~g}$ is attained (Tamime et al., 2014). Straining is done through traditional strainer and centrifugation of curd. Greek yogurts are much thicker in body and heavier in mouth-feel as compared to their stirred counter parts. The product may be considered as intermediate between conventional fermented milks and high moisture, unripened soft cheese such as Quarg (Varnam and Sutherland, 2001). It is also known as Labneh, Turkish yogurt, yogurt cheese, Greek yogurt may also be manufactured by concentrating milk by ultra-filtration or addition of milk solids to make up the total solids in final product before fermentation, then it is referred as Greek-style yogurt. Greek yogurt is currently the largest growing sector in the dairy industry (Pasiacos, 2015). The quality and composition of yogurt of applied bacterial cultures affects the quality of the yogurt obtained as the result of the milk fermentation processes (Brown and Chambers, 2015).

Complex and specific properties of yogurt are determined by the biological characteristics of two species $S$. thermophilus and $L$. bulgaricus, their ratio, biochemical and microbial activities in their mutual development. Yogurt cultures do not ferment galactose moiety of lactose. It may lead to non-enzymatic browning and contribute to off-flavors and other product defects (Anubukkarsi et al., 2014).Therefore, galactose utilizing strains of $S$. thermophilus have potential as a replacement in yogurt 
starter to improve the nutritional quality of finished product. Mixing of defined strains ensures predictability of performance. It offers scope for production of customer-specific cultures that can be adapted to the customer's process and milk quality. It also renders possible the production of cultures with balanced combination of bacterial strains, which is not possible under the traditional starter system. Therefore, this study was carried out to evaluate technological properties of $S$. thermophilus and $L$. delbrueckii ssp. bulgaricus cultures to formulate good quality yogurt and Greek-style yogurt.

\section{Materials and methods}

\section{Bacterial cultures}

Lactic starter cultures comprising of $S$. thermophilus and $L$. bulgaricus were obtained from the National Collection of Dairy Cultures (NCDC), ICAR-National Dairy Research Institute, Karnal (Haryana) and lab isolates of L. bulgaricus were also taken.

\section{Maintenance and propagation of cultures}

The freeze dried preserved cultures were activated in chalk litmus milk (CLM) $\left(42^{\circ} \mathrm{C} / 18 \mathrm{~h}\right)$ and stored under refrigerated conditions $\left(7^{\circ} \mathrm{C}\right)$. Cultures were propagated in sterilized skim milk as and when required. CLM cultures were sub-cultured after every one month and preserved under similar conditions.

\section{Purity of cultures}

The cultures were sub-cultured twice in M-17 and MRS broth for $S$. thermophilus and L. bulgaricus respectively.

\section{Morphological characterization}

The cultures were checked for purity by Gram staining. Thin smear of M17 and MRS broth cultures were prepared on glass slides. The smear was heat fixed and stained using Gram's stain kit (Himedia, Mumbai). After drying, slides were observed under oil immersion objective (100X) for Grams reaction, shape and arrangements of cells. Gram positive cocci and rods in pairs/ chains were further subjected to catalase test.

\section{Catalase test}

The catalase test was performed by slide method. Two to three drops of actively growing culture were transferred on to a clean glass slide and equal number of drops of 3\% hydrogen peroxide solution were poured on it and effervescence was checked. Presence of effervescence indicated a positive catalase reaction, whereas no effervescence was taken as negative test (Norris et al., 1981).

\section{Confirmation of cultures}

The selected cultures were confirmed for their purity by following biochemical tests.

\section{Growth in $6.5 \% \mathrm{NaCl}$, Bile esculin hydrolysis test, Kanamycin esculin test, Citrate azide test and Enterococcus confirmatory test}

M-17 broth tubes with $\mathrm{BCP}(0.004 \%)$ and $6.5 \% \mathrm{NaCl}$ inoculated (a) $1 \%$ and incubated at $42^{\circ} \mathrm{C}$ for $24-48 \mathrm{~h}$. Increase in turbidity and change to yellow colour of broth medium was taken as positive test whereas no increase in turbidity was taken as negative test. The ability to hydrolyse esculin was checked by streaking the active culture on bile esculin agar, Kanamycin esculin agar, Citrate azide agar, and Enterococcus confirmatory agar plates and incubating at $42^{\circ} \mathrm{C}$ for $24 \mathrm{~h}$. The appearance of black colonies on agar plate indicated the hydrolysis of esculin was taken as positive test and no growth on the plates were taken as negative test.

\section{Evaluation of acidification and curd setting profile of cultures in milk (3\% fat, 15\% TS)}

The milk ( $3 \%$ fat and $15 \%$ TS) was heated to $90^{\circ} \mathrm{C}$ for $15 \mathrm{~min}$. The active skim milk culture $\left(42^{\circ} \mathrm{C}\right.$ for $\left.6-8 \mathrm{~h}\right)$ was inoculated (ST and LB - @ $1 \%$ and ST - @ $2 \%$ ) in the milk and incubated at $42^{\circ} \mathrm{C}$ and was observed for curd setting and acidification by measuring the $\mathrm{pH}$.

\section{Evaluation of technological properties of cultures}

Acidification and growth profile in skim milk with 15 and $25 \%$ total solids (TS)

The cultures were initially grown in MRS and M17 broth for $S$. thermophilus and L. bulgaricus and then in sterile reconstituted skim milk for two successive subcultures. The TS of skim milk was adjusted to 15 and $25 \%$ by addition of skim milk powder and was heated to $90^{\circ} \mathrm{C}$ for $15 \mathrm{~min}$. The active skim milk culture $\left(42^{\circ} \mathrm{C}\right.$ for $6-8 \mathrm{~h}$ ) was inoculated in the skim milk and incubated at $42^{\circ} \mathrm{C}$ for $6 \mathrm{~h}$. Sample was drawn at 0 and $6 \mathrm{~h}$ for determination of $\mathrm{pH}$, titratable acidity and viable counts. Based on initial and final viable count growth rate $(\mathrm{K})$ was calculated as follows:

\section{Calculation}

$\mathrm{K}=\mathrm{n} / \mathrm{t}$

$\mathrm{n}=\left(\mathrm{N}_{\mathrm{t}}-\mathrm{N}_{0}\right) / \log 2 \mathrm{t}$

Where,

$\mathrm{N}_{\mathrm{t}}=\log \mathrm{cfu} / \mathrm{ml}$ at $6 \mathrm{~h}, \mathrm{~N}_{0}=\log \mathrm{cfu} / \mathrm{ml}$ at $0 \mathrm{~h}, \mathrm{n}=$ number of generation

$\mathrm{K}=$ Grow rate constant, $\mathrm{t}=$ Time $(\mathrm{h})$.

Acidification profile 
$\mathrm{pH}$ of the sample was monitored with $\mathrm{pH}$ meter (Thermo $\mathrm{pH}$ meter). The titratable acidity was determined by titrating the sample against $\mathrm{N} / 10 \mathrm{NaOH}$ solution using Phenolphthalein as indicator (AOAC, 1999) and expressed as (\% lactic acid)

Acidity $(\%$ lactic acid $)=\frac{9 \times \mathrm{N} \times \mathrm{V}}{W}$

Where,

$\mathrm{V}=$ volume of $\mathrm{N} / 10 \mathrm{NaOH}$ required $(\mathrm{ml}), \mathrm{W}=$ weight of sample taken for analysis $(\mathrm{g})$

$\mathrm{N}=$ normality of the alkali used for neutralization

\section{Enumeration of viable counts}

The sample was serially diluted with normal saline $(0.85 \% \mathrm{NaCl}$ solution). Total ST counts were obtained by plating on M-17 agar $\left(42^{\circ} \mathrm{C}\right.$ for $\left.24-48 \mathrm{~h}\right)$. Total $\mathrm{LB}$ counts were obtained by plating on MRS agar $\left(42^{\circ} \mathrm{C}\right.$ for $\left.24-48 \mathrm{~h}\right)$. The results were expressed in $\mathrm{cfu} / \mathrm{ml}$.

\section{Measurement of proteolytic activity}

The proteolytic activity of $S$. thermophilus and L. bulgaricus in milk was determined by O-Phthaldialdehyde (OPA) method as described by Church et al., (1983). $12 \mathrm{~h}$ activated skim milk culture was inoculated@1\% in 10ml of sterile reconstituted NFDM and incubated $42^{\circ} \mathrm{C}$ and for $6 \mathrm{~h}$. The proteolytic activities were expressed as leucine equivalents, according to standard curve obtained using leucine in a concentration range of $0-25 \mu \mathrm{g} / \mathrm{ml}$.

\section{Evaluation of fermentation of galactose}

\section{Test for galactose fermentation}

The galactose fermentation by $S$. thermophilus strains were carried out using CHL broth containing $1 \%$ galactose. CHL broth tubes were inoculated @ $1 \%$ with cell suspension and incubated at $42^{\circ} \mathrm{C}$ for $24 \mathrm{~h}$. The positive strains gave yellow colour due to decrease in $\mathrm{pH}$ by fermenting galactose (Giraffa et al., 2001; Mora et al., 2002).

\section{Quantification of galactose utilization by gal $^{+}$strain}

The screened galactose positive strains were grown in M-17 broth for $12 \mathrm{~h}$ at $42^{\circ} \mathrm{C}$. The inoculum was prepared as reported by Somkuti and Steinberg (1979) and the cell suspension was inoculated @ 1\% in CHL broth containing 1\% galactose and incubated at $42^{\circ} \mathrm{C}$ and the sample was withdrawn after $6 \mathrm{~h}$ interval for analysis of $\mathrm{pH}$ and sugar content in the medium. The $\mathrm{pH}$ of the media was estimated using $\mathrm{pH}$ meter (Thermo $\mathrm{pH}$ meter). The clear filtrate was analysed for unutilized galactose by HPLC (Shimadzu Corporation, Japan).
Standard galactose and lactose solution $(2 \mathrm{mg} / \mathrm{ml})$ prepared in phosphate buffer and filtered through $0.22 \mu \mathrm{m}$ membrane filter. Quantification of galactose and lactose was accomplished by comparing the peak height of the samples to that of the peak height of standard solutions. The utilized galactose and lactose was detected by comparison with the retention times of standard solution.

\section{Production of flavouring compounds}

\section{Test for acetaldehyde production}

The activated skim milk cultures were inoculated @1\% in skim milk and incubated at $42^{\circ} \mathrm{C} / 6 \mathrm{~h}$. Five millilitres $(5 \mathrm{ml})$ of filtered whey was used for qualitative estimation of acetaldehyde production by $S$. thermophilus cultures using hexamethylenimine and sodium nitroprusside solution. The development of characteristic blue colour was noted (Kroger, 1976).

\section{Test for diacetyl production}

The flavour producing ability of the cultures were screened by modified O' Mearas test described by Hammer (1935) using creatine and sodium hydroxide for production of C-4 carbonyl compound. The active $S$. thermophilus cultures and Lactococcus lactis ssp. lactis biovar diacetylactis (NCDC 193) were inoculated @ $1 \%$ in skim milk and incubated for $6 \mathrm{~h}$. Appearance of pink colour band indicated the positive test for diacetyl production.

\section{Capsular polysaccharide (CPS) production}

The capsule formation around bacterial cell wall of $S$. thermophilus and L. bulgaricus cultures were examined by capsular staining method as described by Anthony (1931). The capsule appeared as halos around the dark stained cells.

\section{Statistical analysis}

All statistical analyses were performed using MS-Excel and Graph-pad Prism statistical tool packages. Results were presented in mean \pm standard deviation (SD).

\section{Results and discussion}

\section{Purity of cultures}

The purity of cultures was checked by evaluating morphology by negative staining, Gram's staining property and catalase test. The $S$. thermophilus cultures were Gram positive cocci in chains and $L$. bulgaricus cultures were Gram positive rods in chains. Absence of evaluation of oxygen bubbles from all the cultures confirmed that strains were catalase negative, which is the characteristic of lactic acid bacteria. Purity of S. thermophilus cultures were further confirmed by different phenotypic tests. The cultures were tested for their growth in M-17 broth in presence 
of $6.5 \% \mathrm{NaCl}$. None of the cultures were showed growth. The active cultures were streaked on Kanamycin asculine agar (KEA), Bile esculin azide agar (BEA), Citrate azide agar (CAA) and Enterococcus confirmatory agar (ECA) plates and incubated at $42^{\circ} \mathrm{C} / 24 \mathrm{~h}$. No growth was observed on agar plates.

\section{Acidification and curd setting profiles of cultures in milk (3\% fat, $15 \%$ TS)}

Curd setting time and acidification profile of $S$. thermophilus cultures were evaluated in combination with L. bulgaricus by inoculating active skim cultures@1\%(ST \& LB) and ST @2\% in milk (heated at $90^{\circ} \mathrm{C}$ for $15 \mathrm{~min}$ then cooled to $40^{\circ} \mathrm{C}$ ) followed by packaging in polystyrene cups. The cups were incubated at $42^{\circ} \mathrm{C}$. Samples were observed at $0.5 \mathrm{~h}$ intervals up to $8 \mathrm{~h}$ for curd setting time. The $\mathrm{pH}$ was measured for single and co-culture set when the first curd setting was observed in any one corresponding set. Among 81 culture combinations, co-culture of ST (NCDC 428, 436, 554) with LB showed similar curd setting time and $\mathrm{pH}$ in combination as well as individual.The curd setting time ranged between 4-4.30 h. Co-cultures of ST (NCDC 526, 455, $454,440,401,435)$ with LB showed lower curd setting time and $\mathrm{pH}$ in combination as compared to individual. The curd setting time for NCDC 526, 455, 454, 440, 401 ranged between 5-5.5 h and for NCDC 435 was $6.5-7 \mathrm{~h}$. Out of 81 combinations 19 culture combinations were found with curd setting time of $4-5 \mathrm{~h}, 53$ with 5-6.5 $\mathrm{h}$ and 6 with 6.5-7.5 h.

Technological properties of selected $S$. thermophilus and $L$. bulgaricus cultures

\section{Acidification and growth profile in skim milk with 15 and} $25 \%$ total solid

The total solids (TS) of skim milk was adjusted to 15 and $25 \%$ by addition of skim milk powder and heated to $90^{\circ} \mathrm{C}$ for $15 \mathrm{~min}$. The active skim milk culture $\left(42^{\circ} \mathrm{C}\right.$ for $\left.6-8 \mathrm{~h}\right)$ was inoculated (@, $\left.1 \%\right)$ in the skim milk and incubated at $42^{\circ} \mathrm{C}$ for $6 \mathrm{~h}$. Sample was drawn at 0 and $6 \mathrm{~h}$ for determination of $\mathrm{pH}$, titratable acidity and viable counts. The acidity of Streptococcus cultures ranged between 0.531 to $0.99 \%$ lactic acid at $15 \%$ TS and 0.549 to $0.961 \%$ lactic acid at $25 \%$ TS. The growth rate of $S$. thermophilus cultures ranged between 1.24 to 1.56 at $15 \%$ and 1.24 to 1.50 at $25 \%$ TS. The acidification profile and growth rate was comparable at 15 and 25\% TS (Figure 1). The growth rate was highest for culture NCDC $526(\mathrm{k}=1.56)$ at $15 \%$ and $(\mathrm{k}=1.50)$ at $25 \%$ TS (Table 1$).$

The acidity of L. bulgaricus cultures ranged between 0.675 to $0.99 \%$ lactic acid at $15 \%$ TS and 0.675 to $0.873 \%$ lactic acid at $25 \%$ TS. The growth rate of Lactobacillus cultures ranged between 0.92 to 1.06 at $15 \%$ and 1.10 to 1.29 at $25 \%$ TS. The acidification profile and growth rate was comparable at 15 and 25\% TS (Figure $2)$. The growth rate was highest for culture HH9 and $\mathrm{I} 15(\mathrm{k}=1.06)$ at $15 \%$ and for Nsp9 $(\mathrm{k}=1.29)$ at $25 \%$ TS (Table 2 and 3$)$.

\section{Proteolytic activity}

The proteolytic activity of cultures was measured in skim milk by inoculating active cultures (@ $1 \%$ ) at $42^{\circ} \mathrm{C}$ for 6 h. The proteolysis was expressed in terms of $\mathrm{mg}$ of leucine $/ \mathrm{ml}$. The proteolytic activity of Streptococcus cultures ranged between $0.087 \pm 0.02$ (NCDC 526) to $0.112 \pm 0.06$ (NCDC 435) $\mathrm{mg}$ of leucine/ml and for LB cultures it was in the range of $0.28 \pm 0.09$ (Nsp9) to $0.42 \pm 0.12$ (I15) $\mathrm{mg}$ of leucine/ml (Figure 3 and Figure 4).

\section{Urease activity}

Five $S$. thermophilus cultures were evaluated for urease activity and 2 strains (NCDC 454, 526) were found as urease positive (Figure 5).

\section{Galactose fermentation and utilization by gal $^{+}$strains}

Table 1 Acidification and growth profile of $S$. thermophilus cultures in skim milk with $25 \%$ TS at $42^{\circ} \mathrm{C}$

\begin{tabular}{|c|c|c|c|c|c|c|c|c|c|}
\hline \multirow[t]{2}{*}{$\overline{\text { Cultures }}$} & \multicolumn{2}{|l|}{$\mathrm{pH}$} & \multirow[t]{2}{*}{$\Delta \mathrm{pH}$} & \multicolumn{2}{|c|}{ Acidity(\% TA) } & \multirow[t]{2}{*}{$\Delta \mathrm{TA}$} & \multicolumn{2}{|c|}{ counts $(\mathrm{cfu} / \mathrm{ml})$} & \multirow[t]{2}{*}{ Growth rate $(\mathrm{k})$} \\
\hline & Oh & $6 \mathrm{~h}$ & & Oh & $6 \mathrm{~h}$ & & $0 \mathrm{~h}$ & $6 \mathrm{~h}$ & \\
\hline NCDC526 & 6.25 & 4.95 & 1.3 & 0.477 & 0.961 & 0.484 & 6.384 & 9.098 & 1.50 \\
\hline NCDC440 & 6.26 & 4.76 & 1.5 & 0.372 & 0.855 & 0.483 & 6.469 & 9.143 & 1.48 \\
\hline NCDC454 & 6.33 & 4.96 & 1.37 & 0.243 & 0.549 & 0.306 & 6.389 & 9.026 & 1.46 \\
\hline NCDC455 & 6.31 & 5.14 & 1.17 & 0.261 & 0.567 & 0.306 & 6.337 & 8.571 & 1.24 \\
\hline NCDC435 & 6.26 & 5.52 & 0.74 & 0.243 & 0.765 & 0.522 & 6.451 & 8.949 & 1.38 \\
\hline
\end{tabular}

Table 2. Acidification profile and growth of L. bulgaricus cultures in skim milk with $15 \%$ TS at $42^{\circ} \mathrm{C}$

\begin{tabular}{llllllllll}
\hline Cultures & $\mathrm{pH}$ & & $\Delta \mathrm{pH}$ & Acidity & $(\% \mathrm{TA})$ & $\Delta \mathrm{TA}$ & counts & $(\mathrm{cfu} / \mathrm{ml})$ & Growth rate $(\mathrm{k})$ \\
\cline { 2 - 8 } & $0 \mathrm{~h}$ & $6 \mathrm{~h}$ & & $0 \mathrm{~h}$ & $6 \mathrm{~h}$ & & $0 \mathrm{~h}$ & $6 \mathrm{~h}$ & 1.06 \\
HH9 & 6.35 & 4.54 & 1.81 & 0.288 & 0.999 & 0.711 & 6.97 & 8.9 & 1.06 \\
I15 & 6.34 & 4.66 & 1.68 & 0.252 & 0.99 & 0.738 & 7.49 & 9.417 & 0.92 \\
Nsp9 & 6.49 & 5.17 & 1.32 & 0.342 & 0.675 & 0.333 & 6.822 & 8.491 & \\
\hline
\end{tabular}


Figure 1: Comparison of growth rate of

$S$.

thermophilus cultures in skim milk with 15 and $25 \%$ TS

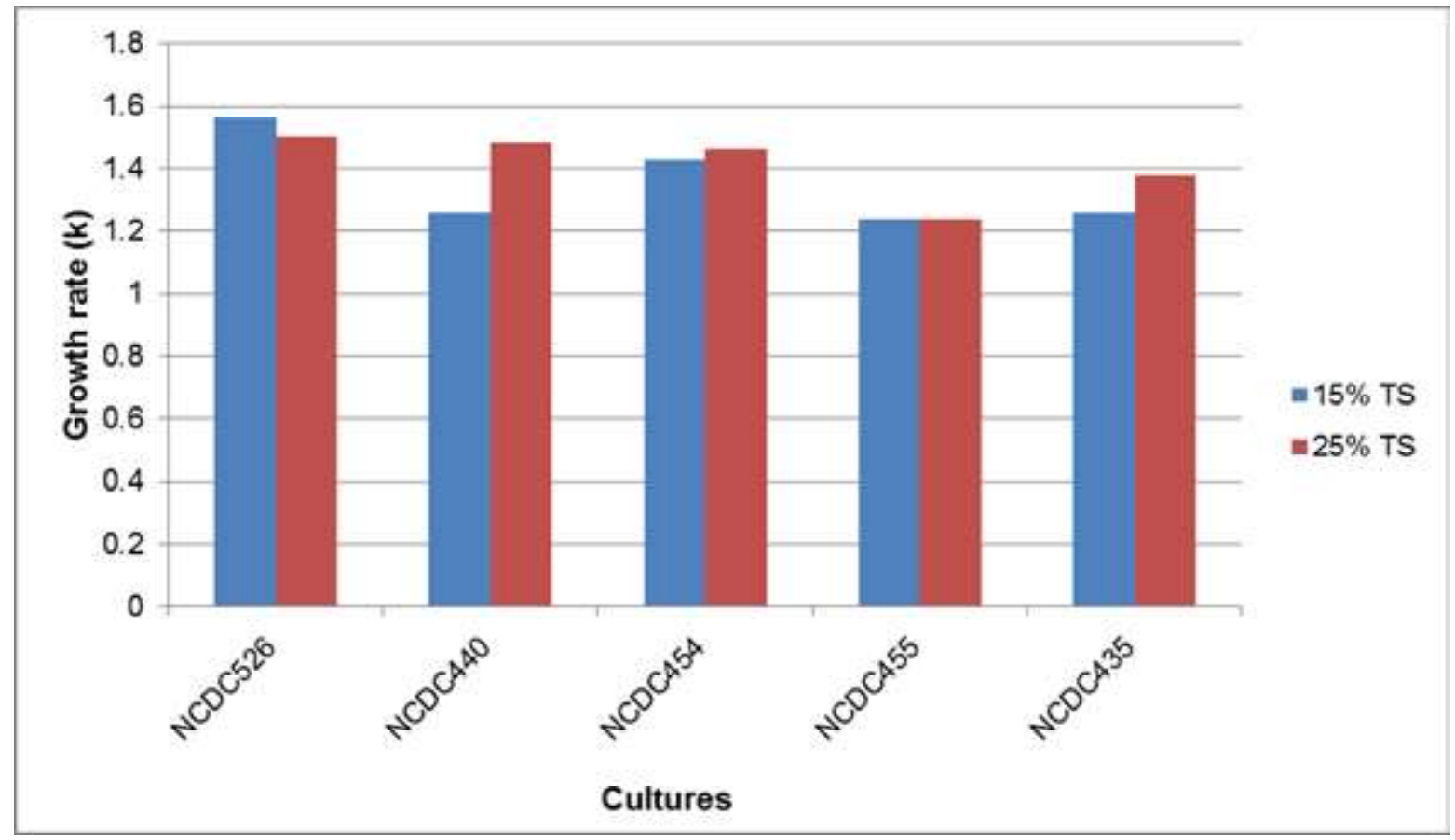

Figure 2: Comparison of growth rate of $L$. bulgaricus cultures in skim milk with 15 and $25 \%$ TS

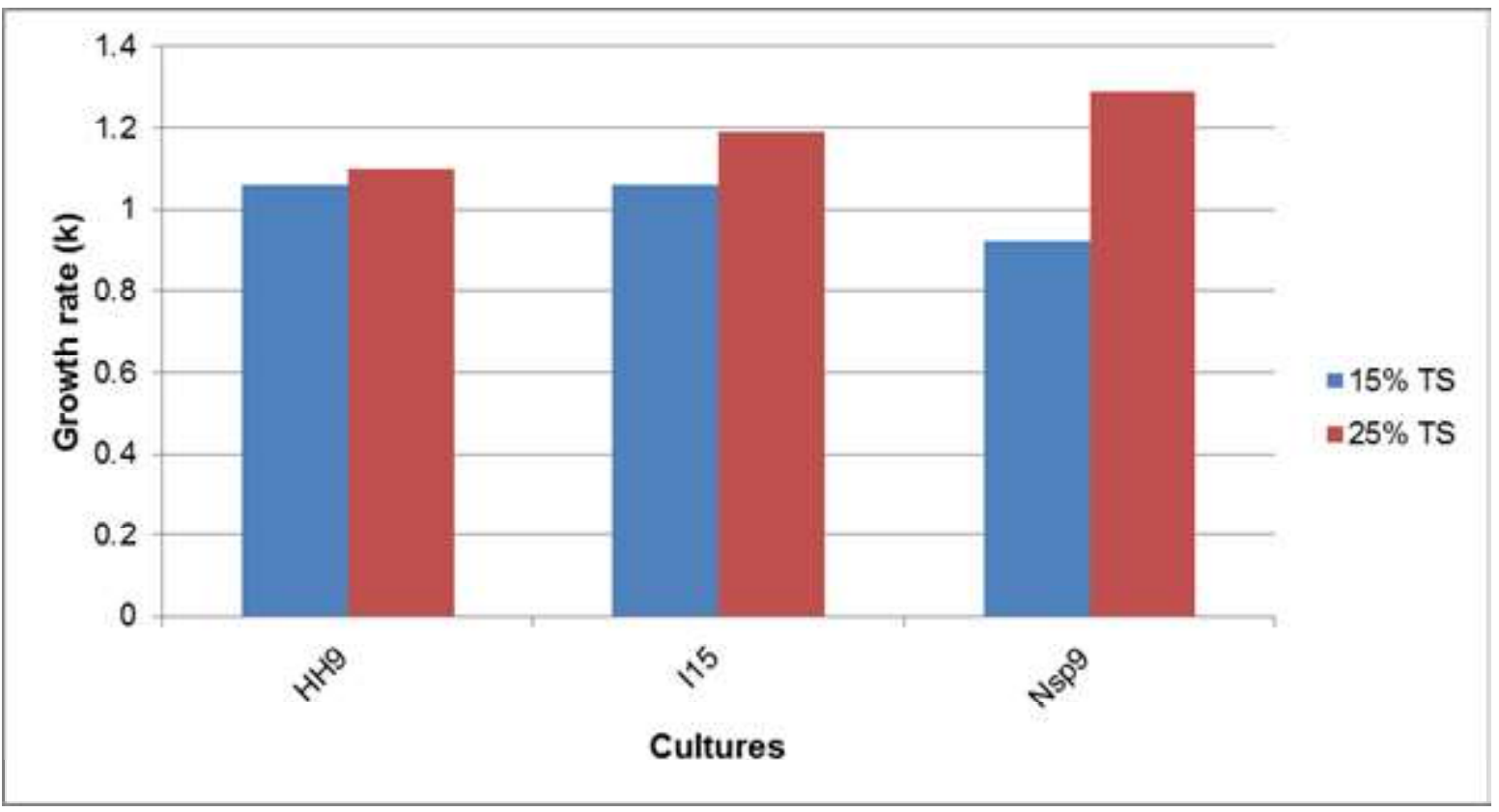

Galactose fermenting strains of S. thermophilus are designated as atypical because majority of them do not ferment galactose. The galactose catabolising strains have their own importance in producing low galactose mozzarella cheese and yogurt which may be used by spoilage or pathogenic microorganisms or may cause browning effects are of technological importance. All 5 strains were galactose positive.
In the present work, the galactose positive strains were grown for $6 \mathrm{~h}$ at $42^{\circ} \mathrm{C}$ in $\mathrm{CHL}$ broth containing $1 \%$ lactose. The amount of galactose and lactose fermented by $S$. thermophilus strains were evaluated by measuring the residual sugar present in CHL broth by HPLC (Figure 6). The change in $\mathrm{pH}$ of CHL broth was ranged between 1.95 to 2.26 (Figure 7). The amount of galactose utilization was ranged between 50 to $83.4 \%$. NCDC 435 was found with highest galactose utilizing potential as compared to other stains (Table 4). 
Figure 3: Proteolytic activity of S. thermophilus cultures at $42^{\circ} \mathrm{C} /$ $6 \mathrm{~h}$

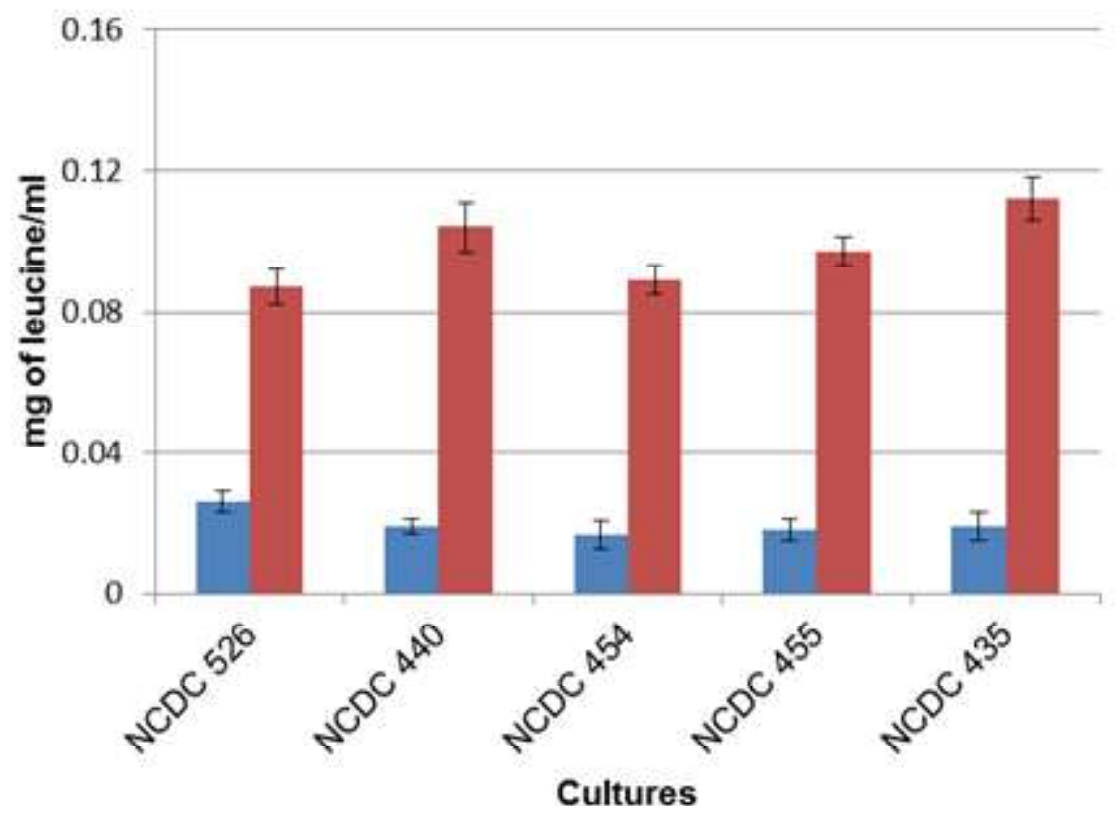

Figure 4: Proteolytic activity of Lb. bulgaricus cultures at $42^{\circ} \mathrm{C} / 6 \mathrm{~h}$.

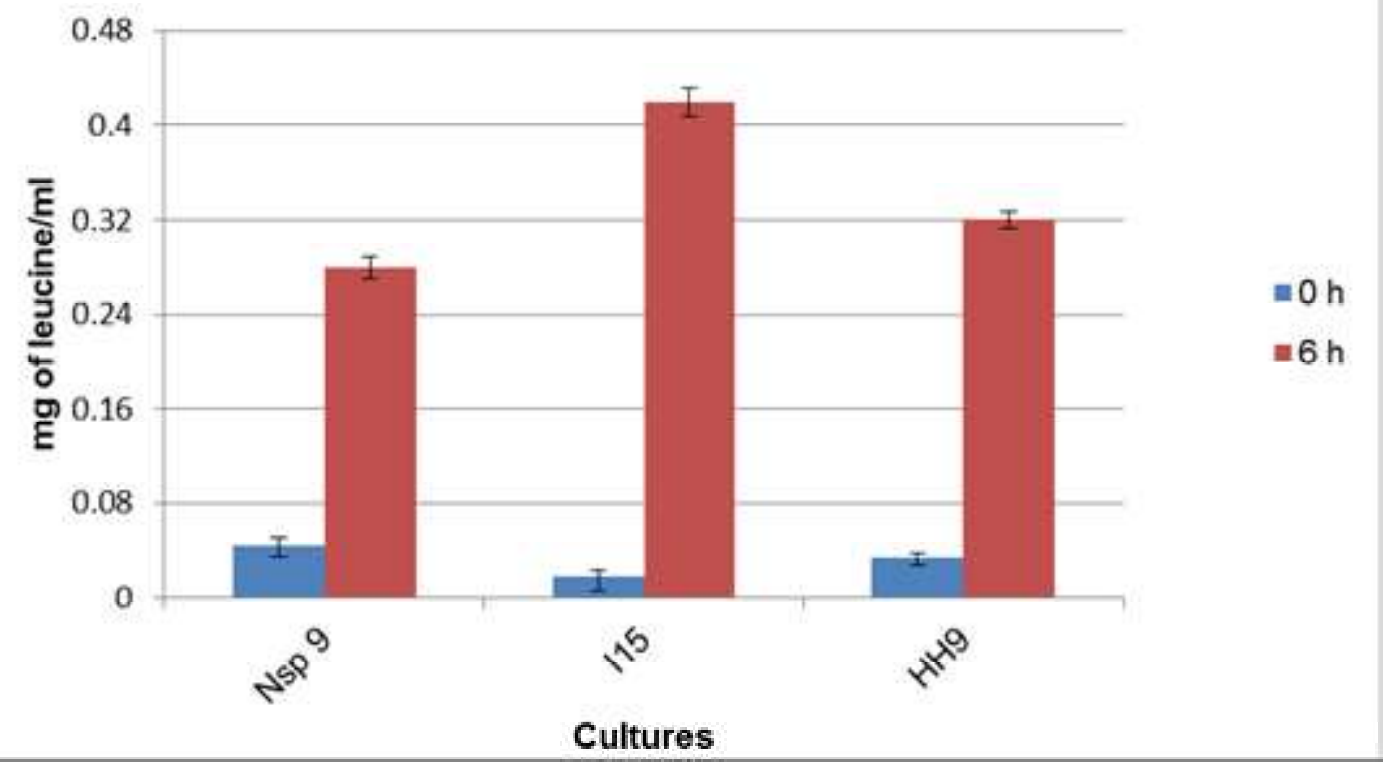

\section{Production of flavouring compounds}

All the five cultures (NCDC 435, 455, 454, 435, and 526) were positive for acetaldehyde production at $42^{\circ} \mathrm{C} / 6 \mathrm{~h}$. The flavour of yogurt is originated from non-volatile acid, carbonyl compound, amino acids and free fatty acids. Among these, the most important carbonyl compound is acetaldehyde. Diacetyl production by $S$. thermophilus is strain dependent, since some strains produced and some did not produced diacetyl. All the five cultures (NCDC $435,455,454,435,526)$ were negative for diacetyl production at $42^{\circ} \mathrm{C} / 6 \mathrm{~h}$ (Table 5).

\section{Capsular polysaccharide (CPS) production}


Figure 5: Urease activity of $S$. thermophilus cultures (urea broth at $\left.42^{\circ} \mathrm{C}\right)$
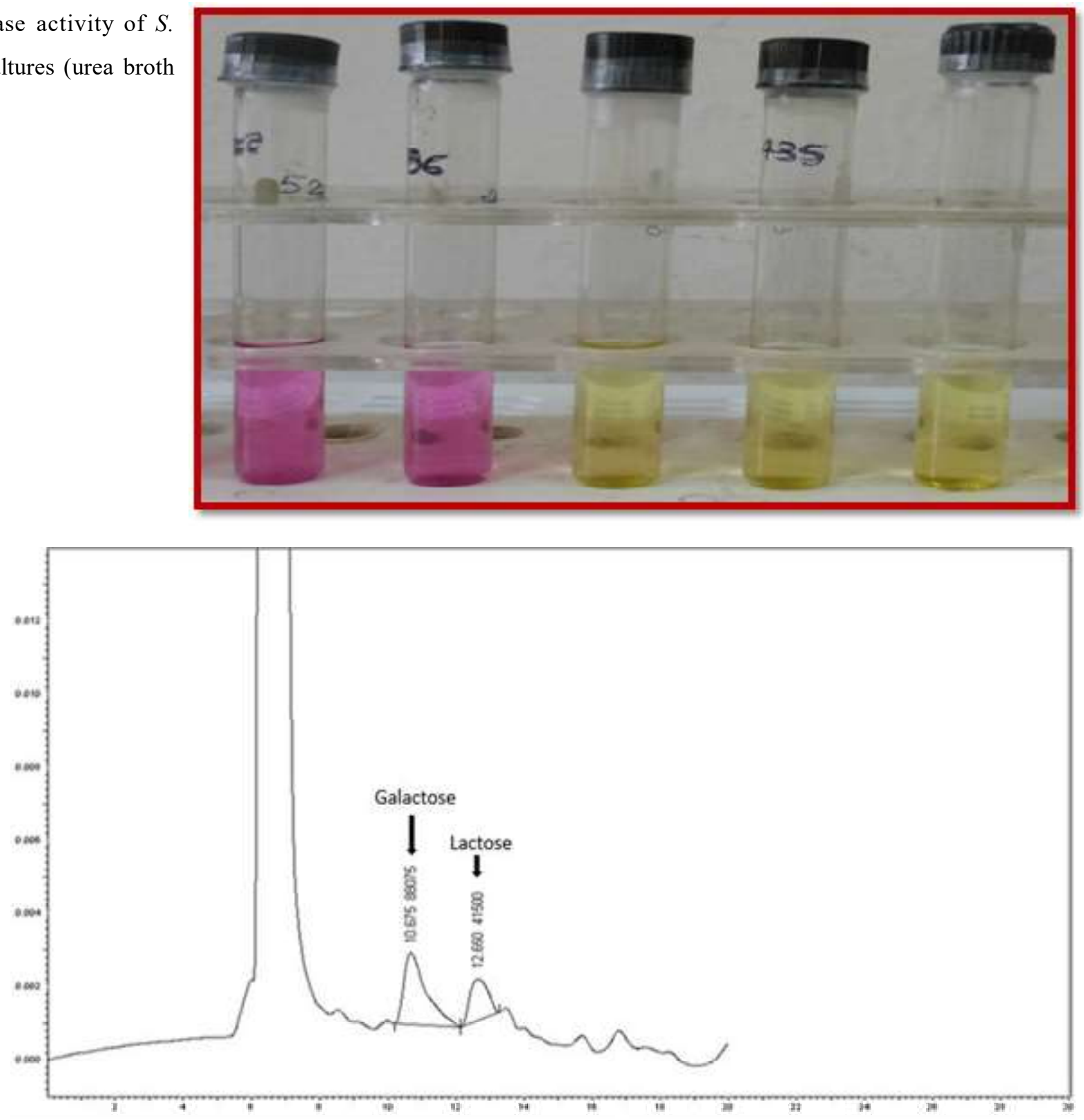

Figure 6: HPLC chromatographs of lactose and galactose utilization by NCDC $526\left(\mathrm{CHL}\right.$ broth, $1 \%$ filter sterilized lactose, $42^{\circ} \mathrm{C} / 6$

h)

The ability to produce capsular polysaccharide was tested by capsular staining method and all five $S$. thermophilus and $L$. bulgaricus cultures were positive for capsule production

Technological properties of selected $S$. thermophilus and $L$. bulgaricus cultures

Purity, Acidification and growth profile in skim milk with 15 and $25 \%$ total solids

Streptococcus thermophilus and Enterococcus are closely related species in terms of their nutritional and growth requirements. There are chances for frequent contamination of cultures with
Enterococci during different steps of isolation, maintenance and preservation. So, it is important to check the purity of cultures before selection. Cultures are not able to hydrolyse esculin which differentiates it from other species as S. bovis, S. lactis and Enterococcus sp. were indicated there is no contamination with Enterococci.

The growth rate of $S$. thermophilus and L. bulgaricus were comparable at 15 and $25 \%$ total solid level. Ozer and Robinson (1999) showed that increasing of milk total solids from 16 to $23 \mathrm{~g} /$ $100 \mathrm{~g}$ improved the growth of L. bulgaricus where counts of this organism after 240 minutes in $23 \%$ TS were highest. Our results 
Figure 7: Reduction in $\mathrm{pH}$ and amount of galactose utilized by S. thermophilus cultures in CHL broth at $42^{\circ} \mathrm{C} / 6 \mathrm{~h}$.

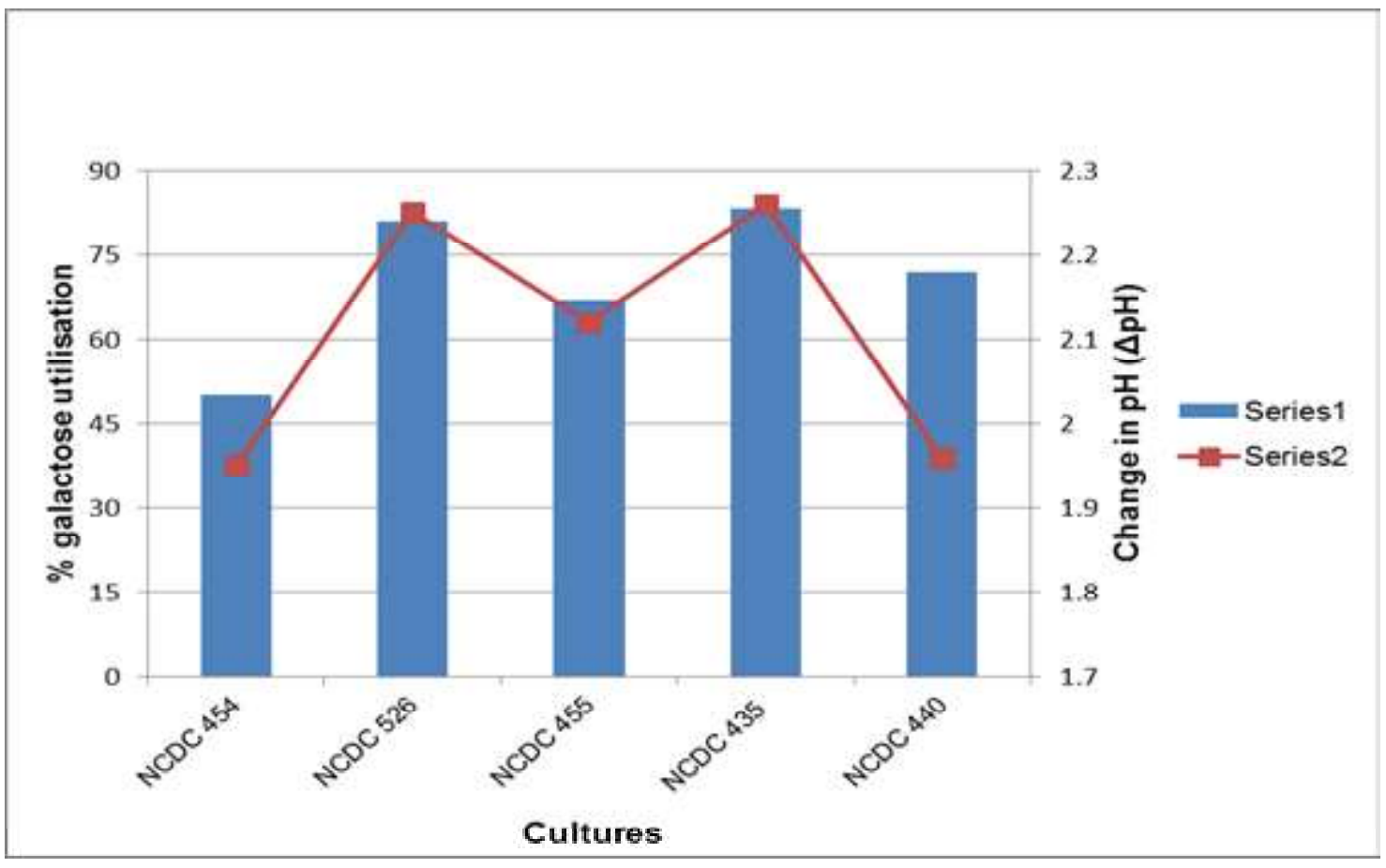

Table 3 Acidification profile and growth of $L$. bulgaricus cultures in skim milk with $25 \%$ TS at $42^{\circ} \mathrm{C}$

\begin{tabular}{|c|c|c|c|c|c|c|c|c|c|}
\hline \multirow[t]{2}{*}{$\overline{\text { Cultures }}$} & \multicolumn{2}{|l|}{$\mathrm{pH}$} & \multirow[t]{2}{*}{$\Delta \mathrm{pH}$} & \multicolumn{2}{|c|}{ Acidity } & \multirow[t]{2}{*}{$\Delta \mathrm{TA}$} & \multicolumn{2}{|c|}{ counts $(\mathrm{cfu} / \mathrm{ml})$} & \multirow[t]{2}{*}{ Growth rate $(\mathrm{k})$} \\
\hline & $\mathrm{Oh}$ & $6 \mathrm{~h}$ & & $\mathrm{Oh}$ & $6 h$ & & Oh & $6 \mathrm{~h}$ & \\
\hline$\overline{\mathrm{HH} 9}$ & 6.39 & 5.31 & 1.08 & 0.41 & 0.873 & 0.459 & 6.70 & 8.69 & 1.10 \\
\hline $\mathrm{I} 15$ & 6.33 & 5.15 & 1.18 & 0.42 & 0.675 & 0.252 & 7.419 & 8.732 & 1.19 \\
\hline Nsp9 & 6.35 & 5.36 & 0.99 & 0.423 & 0.855 & 0.432 & 6.599 & 8.92 & 1.29 \\
\hline
\end{tabular}

Table 4 Galactose fermentation by gal ${ }^{+}$cultures in $\mathrm{CHL}$ broth incubated at $42^{\circ} \mathrm{C} / 6 \mathrm{~h}$

\begin{tabular}{lllc}
\hline Cultures & Change in $\mathrm{pH}(\Delta \mathrm{pH})$ & \% Utilisation & Lactose \\
\cline { 2 - 4 } & & Galactose & 79.3 \\
NCDC 454 & 1.95 & 50.0 & 96.9 \\
NCDC 526 & 2.25 & 81.1 & 91.7 \\
NCDC 455 & 2.12 & 66.9 & 96.2 \\
NCDC 435 & 2.26 & 83.4 & 91.5 \\
NCDC 440 & 1.96 & 72.0 & \\
\hline
\end{tabular}

Table 5 Flavour profile of $S$. thermophilus cultures in skim milk at $42^{\circ} \mathrm{C} / 6 \mathrm{~h}$

\begin{tabular}{lll}
\hline Cultures & Acetaldehyde production & Diacetyl production \\
\hline NCDC-435 & ++ & - \\
NCDC-454 & ++ & - \\
NCDC-455 & ++ & - \\
NCDC-526 & $+1+$ & - \\
NCDC-440 & + & - \\
\hline
\end{tabular}

are in good agreement for selection of starter culture for preparation of Greek-style yogurt (Desai et al., 2013). Since the primary role of starter culture is faster acidification within fixed time period. 


\section{Proteolytic activity}

There has been growing interest in the proteolytic systems of lactobacilli and streptococci owing to their wider inclusion as starter cultures in fermented milks. S. thermophilus strains are described as weakly proteolytic manifesting a limitation of essential amino acids in milk for growth and metabolism (Rodriguez-Serrano et al., 2018). S. thermophilus exhibits a very low membrane bound proteinase system mainly consists of peptidases (Simova and Beshkova, 2007). However, they do cause a significant degree of proteolysis in yogurt. Lactobacilli are more proteolytic than streptococci and have more ability to hydrolyze casein. Proteinase activity of $S$. thermophilus is limited, but peptidase activity can hydrolyze the intermediate products of casein proteolysis from L. bulgaricus, which is an important aspect of the synergistic relationship between the two organisms in yogurt. Badis et al. (2004) reported lower proteolytic activity i.e., $<4 \mu \mathrm{g} / \mathrm{ml}$ of tyrosine after $24 \mathrm{~h}$ for $S$. thermophilus isolates. Abu-Tarboush (1996) used OPA method for studying the proteolytic activity of 4 S. thermophilus strains TH3, TH4, 36 and 37 and reported to produce 7.9, 10.0, 8.3 and 7.0 $\mu \mathrm{g}$ of Leu$\mathrm{Gly} / \mathrm{ml}$ respectively after $4 \mathrm{~h}$ in whole cow milk.

\section{Urease activity}

Among lactic acid bacteria involved in dairy fermentation processes, urease activity is present only in S. thermophilus. Zotta et al. (2008) screened out 205 strains belonging to 27 species of LAB for urease production and only S. thermophilus hydrolyzed urea. They reported that $79 \%$ of $S$. thermophilus strains to be positive and the remaining strains (21\%) as negative for urease. Urease production is strain dependent trait. Our results are in good agreement with these findings as two cultures out of five we tested were urease positive. It has been regarded as detrimental for its activity as starter culture in yogurt and cheese production because milk acidification is delayed by the production of ammonia. However, urease production has been proposed to provide an additional nitrogen source which results in higher cell numbers and may reduce cell damage at acid $\mathrm{pH}$, thus resulting in higher activity in bulk cultures. Moreover, urea can be used to keep $\mathrm{pH}$ constant during lactic acid fermentation or biomass production for making concentrated starter preparations (Mora et al. 2004).

\section{Galactose fermentation}

S. thermophilus prefers the disaccharides lactose and sucrose, and its growth on the constituent monosaccharides, glucose, fructose and galactose is slower than the disaccharides. It has been reported that when cells are grown on excess lactose, galactose accumulates in the medium. Even those strains, which ferment free galactose, do not ferment in the presence of glucose (Hutkins and Ponne, 1991). This phenomenon has been explained with the findings that the enzymes of the Leloir pathway for galactose metabolism are present in S. thermophilus, however their activities are very low and the activity of the first enzyme galactokinase is undetectable under normal growth conditions (Grossiord et al., 1998). Galactose-positive strains of $S$. thermophilus may be valuable for the dairy industry to prevent problems caused by the accumulation of galactose in fermented milk products (Vaughan et al., 2001). Since Gal positive cultures are unstable when maintained in milk, reverting to the Gal negative phenotype, care must be taken with culture maintenance (Erkus et al., 2014). Our data and those reported by Giraffa et al. (2001) are consistent with the hypothesis that galactose-fermenting strains are commonly present in S. thermophilus.

\section{Capsular polysaccharide (CPS) production}

Capsules produced by lactic acid bacteria (LAB) were reported to improve yogurt viscosity, enhances texture and mouthfeel, and avoids syneresis during fermentation, impart texture in reduced fat dairy products, may act as a barrier to acid diffusing from the cell, may protect the cell from bacteriophages, antibodies, and bacteriocins (Zhu et al., 2018; Khalil et al., 2007). Our study are consistent with the hypothesis that all cultures were capsule producing as CPS producing culture improve the body and texture of finished product.

\section{Conclusions}

The results suggest that NCDC 526 and I15 can be selected on the basis of technological properties as good starter culture candidates for producing yogurt. The results obtained in the study revealed that growth and acidification profile of cultures S. thermophilus (NCDC 526, 455, 454, 435, 454) and L. bulgaricus (I15, HH9, Nsp9) were comparable in skim milk with 15 and 25\% TS. NCDC 526 found with lowest and I15 with highest proteolytic activity. NCDC 435 was found with highest galactose utilising potential as compared to other cultures. All S. thermophilus cultures were positive for acetaldehyde production and negative for diacetyl production. All S. thermophilus and L. bulgaricus cultures were found positive for CPS production. Further, study is however required to evaluate the selected strains individually and in mixed cultures.

\section{Acknowledgements}

The first author acknowledges Indian Council of Agriculture Research (ICAR) National Dairy Research Institute, Karnal (India) for the grant of Junior Research Fellowship (JRF).

\section{References}

Abu-Tarboush HM (1996) Comparison of associative growth and proteolytic activity of yogurt starters in whole milk from camels and cows. J Dairy Sci 79: 366-371

Anbukkarasi K, UmaMaheswari T, Hemalatha T, Nanda DK, Singh P, Singh R (2014) Preparation of low galactose yogurt using cultures of $\mathrm{Gal}^{+}$Streptococcus thermophilus in combination with 
Lactobacillus delbrueckii ssp. bulgaricus. J Food Sci Tech 51(9): 2183-2189

Anthony Jr EE (1931) A note on capsule staining. Science (New York, NY)73: 319-320.

Association of Official Analytical Chemists (1999) In: Official methods of analysis of AOAC international, 16th ed P. Cuniff (Ed.), Vol. II. Maryland, USA

Badis A, Guetarni D, Moussa-Boudjemaa B, Henni DE, Tornadijo ME, Kihal M (2004) Identification of cultivable lactic acid bacteria isolated from Algerian raw goat's milk and evaluation of their technological properties. Food Microbiol 21: 343-349

Brown MD, Chambers DH (2015) Sensory characteristics and comparison of commercial plain yogurts and 2 new production sample options. J Food Sci 80: S2957-S2969

Church FC, Swaisgood HE, Porter DH, Catignani GL (1983) Spectrophotometric assay using o-phthaldialdehyde for determination of proteolysis in milk and isolated milk proteins. $\mathrm{J}$ Dairy Sci 66: 1219-1227

Desai, NT, Shepard L, Drake MA (2013) Sensory properties and drivers of liking for Greek yogurts. J Dairy Sci 96: 7454-7466

Erkus O, Okuklu B, Yenidunya AF, Harsa S (2014) High genetic and phenotypic variability of Streptococcus thermophilus strains isolated from artisanal Yuruk yoghurts. LWT - Food Sci Technol 58(2): 348354

Giraffa G, Paris A, Valcavi L, Gatti M, Neviani E (2001) Genotypic and phenotypic heterogeneity of Streptococcus thermophilus strains isolated from dairy products. J Appl Microbiol 91: 937-943

Grossiord B, Vaughan EE, Luesink E, De Vos WM (1998) Genetics of galactose utilisation via the Leloir pathway in lactic acid bacteria. Le Lait 78:77-84

Hammer BW (1935) Reduction of acetylmethylcarbinol and diacetyl to 2, 3-butylene glycol by the citric acid fermenting streptococci of butter cultures.Ia Agr Exp Sta Res Bul 191:381-407

Hutkins RW, Ponne C (1991) Lactose uptake driven by galactose efflux in Streptococcus thermophilus: evidence for a galactose-lactose antiporter. Appl Environ Microbiol 57: 941-944

Jorgensen CE, Abrahamsen RK, Rukke EO, Hoffmann TK, Johansen AG, Skeie SB (2018) Processing of high-protein yoghurt- A review. Int Dairy J 88: 42-59

Khalil R, Frank JF, Hassan AN, Omar SH (2007) Inhibition of phage infection in capsule-producing Streptococcus thermophilus using concanavalin A, lysozyme and saccharides. Afr J Biotechnol 6: 22802286

Kroger M (1976) Quality of yogurt. J Dairy Sci 59: 344-350
Mora D, Fortina MG, Parini C, Ricci G, Gatti M, Giraffa G, Manachini PL (2002) Genetic diversity and technological properties of Streptococcus thermophilus strains isolated from dairy products. J Appl Microbiol 93: 278-287

Mora D, Maguin E, Masiero M, Parini C, Ricci G, Manachini PL, Daffonchio D (2004) Characterization of urease genes cluster of Streptococcus thermophilus. J Appl Microbiol 96: 209-219

Norris JR, Berkeley RCW, Logan NA, O'Donnell AG (1981) The genera Bacillus and Sporolactobacillus. p. 1711-1742. In M.P. Starr et al. (ed.). The prokaryotes. Springer Verlag, New York

Ozer BH, Robinson RK (1999) The behaviour of starter cultures in concentrated yoghurt (labneh) produced by different techniques. LWT-Food SciTechnol 32: 391-395

Pasiakos SM (2015) Metabolic advantages of higher protein diets and beneûts of dairy foods on weight management, glycemic regulation, and bone. J Food Sci 80: A2-A7

Rodríguez-Serrano GM, Garcia-Garibay JM, Cruz-Guerrero AE, GomezRuiz LDC, Ayala-Nino A, Castaneda-Ovando A, Gonzalez-Olivares LG (2018) Proteolytic system of Streptococcus thermophilus: A review. Int J Microbiol Biotechnol DOI: 10.4014/jmb.1807.07017

Simova E, Beshkova D (2007) Effect of growth phase and growth medium on peptidase activities of starter lactic acid bacteria. Le Lait 87: 555-573

Somkuti G, Steinberg D (1979) Adaptability of Streptococcus thermophilus to lactose, glucose and galactose. J Food Prot 42: 885-887

Tamime AY, Hickey M, Muir DD (2014) Strained fermented milks: a review of existing legislative provisions, survey of nutritional labelling of commercial products in selected markets and terminology of products in some selected countries. Int J Dairy Tech 67: 305333

Varnam A, Sutherland JP (2001) Milk and milk products: Technology, Chemistry and Microbiology. Aspen Publishers.Gaithersburg. Maryland

Vaughan EE, van den Bogaard, Patrick TC, Catzeddu P, Kuipers OP, de Vos WM (2001) Activation of Silent gal Genes in the lac-gal Regulon of Streptococcus thermophilus. J Bacteriol 183: 1184-1194

Zhu Y, Wang X, Pan W, Shen X, He Y, Yin H, Zhou K, Zou L, Chen S. Liu, S (2018) Exopolysaccharides produced by yogurt-texture improving Lactobacillus plantarum RS20D and the immuno-regulatory activity. ýInt J Biol Macromol 121: 342-349

Zotta T, Ricciardi A, Rossano R, Parente E (2008) Urease production by Streptococcus thermophilus. Food Microbiol 25: 113-119 